\begin{tabular}{|c|l|}
\hline Title & $\begin{array}{l}\text { A sperm cryopreservation protocol for the loach Misgurnus anguillicaudatus and its applicability for other related } \\
\text { species }\end{array}$ \\
\hline Author(s) & Y asui, George Shigey uki; A rias Rodriguez, Lenin; Fujimoto, Takafumi; A rai, Katsutoshi \\
\hline Citation & $\begin{array}{l}\text { Animal Reproduction Science, 116(3-4), 335-345 } \\
\text { https://doi.org/10.1016/.anireprosci.2009.02.021 }\end{array}$ \\
\hline Issue Date & 2009-12 \\
\hline Doc URL & http://hdl.handle.net/2115/42542 \\
\hline Type & article (author version) \\
\hline File Information & arai_ARS116.pdf \\
\hline
\end{tabular}

Instructions for use 


\title{
A sperm cryopreservation protocol for the loach Misgurnus anguillicaudatus and its applicability for other related species
}

George Shigueki Yasui ${ }^{1}$, Lenin Arias-Rodriguez ${ }^{1,2}$, Takafumi Fujimoto ${ }^{1}$ and Katsutoshi Arai ${ }^{1}$

${ }^{1}$ Hokkaido University, Graduate School of Fisheries Sciences, Laboratory of Aquaculture Genetics and Genomics, 3-1-1 Minato-cho, Hakodate, Hokkaido, 041-8611, Japan. E-mail: george@fish.hokudai.ac.jp

${ }^{2}$ División Académica de Ciencias Biológicas, UJAT, C.P. 86150 Villahermosa, Tabasco, México.

\begin{abstract}
The aim of the present study was to establish a protocol of sperm cryopreservation in Misgurnus anguillicaudatus and verify the applicability of the obtained protocol in other loach species. We evaluated the following parameters: inseminating dose, thawing temperatures (20, 25 and $30^{\circ} \mathrm{C}$ for 10 s), extenders (loach or cyprinid extenders), internal cryoprotectants (Dimethyl sulfoxide - DMSO, Dimethylacetamide - DMA, glycerol - Gly, ethylene glycol - EG, and methanol - $\mathrm{MeOH}$ at 0, 5, 10 and 15\%), external cryoprotectants (Bovine serum albumin 1 and 2\%; sucrose 0.5 and 1\%; glucose 0.5 and 1\%; glycine 0.5 and 1\%), activating solutions (distilled water, dechlorinated tap water, $25 \mathrm{mM} \mathrm{NaCl}$ and $50 \mathrm{mM}$ $\mathrm{NaCl}$ ), and hatchability of the eggs when fertilized with fresh or cryopreserved sperm. After the evaluation of these parameters, we optimized the cryopreservation using the following procedure: thawing temperature at $25^{\circ} \mathrm{C}$ for $10 \mathrm{~s}$; loach or cyprinid extenders; methanol at 10 or $15 \%$ as internal cryoprotectants; glycine $0.5 \%$ or bovine serum albumin $1 \%$ as external
\end{abstract}


cryoprotectants and 50mM NaCl for sperm activation. Using this procedure, the fertilizability of the post-thawed sperm was $47 \%$ in comparison to the fresh sperm, at the minimum inseminating dose (687.65 sptz $\left.\mathrm{egg}^{-1} \mathrm{~mL}^{-1}\right)$. Based on this protocol, sperm from other loach species Lefua nikkonis, M. mizolepis and Barbatula toni were cryopreserved successfully.

Keywords: cryopreservation, fish, inseminating dose, loach, Misgurnus, sperm.

\section{Introduction}

The family Cyprinidae is divided into two monophyletic superfamilies: Cyprinoidae and Cobitoidae (Nelson, 2006). Although some controversies exists regarding its taxonomy, the recent research indicates that the superfamily Cobitoidea is composed by seven families five of which make a family group referred to as loaches (see Slechtová et al., 2007 and 2008). In East Asia, the loach Misgurnus anguillicaudatus is an important specie regarding aquaculture and inland fisheries. This specie is also distributed in other Eurasian countries. From the viewpoint of basic and academic research, the loach is interesting because it includes polyploids and unisexual biotypes in nature (see Arai 2001, 2003). Due to its significance in inland aquaculture, chomosome manipulation techniques such as induced gynogenesis, androgenesis and polyploid have been established for genetic improvement of farmed strains (see Arai, 2001; 2003). Recently, cloning by nuclear transplantation of somatic cells (Tanaka et al., 2009), transgenics (Nam et al., 2001), germ-line chimeras (Nakayama et al., 2008) are also reported in the loach. Thus, the loach $M$. anguillicaudatus is an important specie from the viewpoint of both, basic biology and applied practice. For further expansion of basic and applied studies using the loach as a model animal, cryopreservation techniques of gametes are necessary to carry out molecular and cellular techniques responsible for gametogenesis and heredity. Other loach species such as the 
European M. fossilis, Cobitis sp. and the Japanese Lepdobotia curta are now reducing their natural stocks due to the degradation of their environments and such situation led to many research efforts in genetics and reproduction of loaches (Abe et al., 2007; AdámkováStibranyiová et al., 1999; Aoyama and Doi, 2005; Bohlen et al., 1999; Watanabe et al., 2008). Although there is a consense that enviromental preservation is the best procedure for the maintainance of those species, it is required long-term genebanking methods to preserve the loach species from their extinction. Cryopreserved sperm is a reliable procedure for the maintenance of fish species because of its relative easiness for freezing and storage. In addition, fish species can be replaced from the cryopreserved sperm using artificially-induced androgenesis, providing only the male inheritance. In the case of $M$. anguillicaudatus, the protocol of androgenesis was already established in our previous works (Arai et al., 1995; Fujimoto et al., 2007; Masaoka et al., 1995). Androgenesis was also achieved in other fish species using heterologous gametes (Bercsenyi et al., 1998; Nam et al., 2001) and homologous dispermic fertilization (Araki et al., 1995). Considering the advances in artificial propagation and androgenesis mentioned above, it may facilitate the applicability of the cryopreserved sperm as a repository genebank. However, as far as we know, there are only few studies regarding sperm cryopreservation in loach species (Kopeika et al., 2003, 2004) and no protocol for the M. anguillicaudatus at present.

In the present study, we develop a protocol of sperm cryopreservation for the loach Misgurnus anguillicaudatus in order to constitute a genebank. In addition, we also verified the applicability of this procedure in other loach species for future application as a sperm bank. 


\section{Material and methods}

\subsection{Induced maturation, assessment of sperm motility and cryopreservation}

Adult male loaches (Misgurnus anguillicaudatus) from Iwamizawa city (Hokkaido, Japan) were anaesthetized with 2-phenoxyethanol $\left(1 \mathrm{~mL} \mathrm{~L}^{-1}\right)$, and then induced maturation by human chorionic gonadotropin - hCG injection (100 IU/male and $500 \mathrm{IU} /$ female). Fishes were maintained at $27^{\circ} \mathrm{C}$ for 10 hours, and then sperm was collected in hematocrit glass tubes by gently squeezing the abdomen. Samples were immediately placed in a $1.5 \mathrm{~mL}$ macrotubes containing 1mL of immobilizing solution (128.4 mM NaCl, $2.7 \mathrm{mM} \mathrm{KCl,} 1.4 \mathrm{mM} \mathrm{CaCl}, 2.4$ mM NaHCO 3 ) (Kurokura et al., 1984), followed by vortexing.

Sperm was activated by a 70-fold dilution with dechlorinated tap water - DTW (2 days of incubation after collection from tap) and observed under the microscope. Slides were covered with a $0.5 \%$ bovine serum albumin (BSA) solution in order to prevent sperm adhesion to the glass. The motility analyses were conducted in triplicates and video recorded (Sharp VHS VC-HF920). Total motility (\%), progressive motility (\%) and its duration (s) were obtained from video sequences from subjective visualization of sperm movement, (Trippel and Neilson, 1992; Iwamatsu et al., 1993). Total motility denotes any type of movement and was expressed as percentage of all the cells observed in the same field. Progressive motility regards to sperm movement along a linear track, and it was expressed as percentage of the motile cells. The duration of motility regards to the elapsed time of progressive movement, and it was measured from the sperm activation until $5 \%$ of progressive motility.

Samples with total motility higher than $90 \%$ were pooled. The final concentration of such pool was $5.8 \times 10^{8}$ cells $\mathrm{mL}^{-1}$, verified using hemocytometer.

The sperm was then diluted 7-fold using the diluent, vortexed, packed in $250 \mu \mathrm{L}$ cryogenic straws - with the final volume adjusted to $140 \mu \mathrm{L}$ by cutting. The straws were 
sealed using straw powder and frozen using the tube method recently described by Yasui et al. (2008). The straws were inserted in a plastic cooling tube and then placed into powdered dry ice for two minutes. This procedure resulted in the following cooling characteristics inside the tube: final temperature at $-57.9 \pm 1.57^{\circ} \mathrm{C} / \mathrm{min}$; total cooling rate at $-30.9 \pm 0.79^{\circ} \mathrm{C} / \mathrm{min}$; cooling rate from $4^{\circ}$ to $0^{\circ} \mathrm{C}$ at $-18.0 \pm 0.76^{\circ} \mathrm{C} / \mathrm{min}$; cooling rate from 0 to $-50^{\circ} \mathrm{C}$ at $-33.3 \pm$ $2.09^{\circ} \mathrm{C} / \mathrm{min}$. After two minutes into powdered dry ice, the straws were taken from the tubes and plunged directly into liquid nitrogen for storage.

\subsection{Inseminating dose for loach eggs}

Eggs from two females and sperm from three males were obtained using the previous procedure. Eggs were stripped into a $50 \mathrm{~mL}$ conical tube (Falcon, Inc.), adjusted to $15 \mathrm{~mL}$ by cutting. One hundred micro-litters of eggs (292.8 \pm 13.9 eggs) were pippeted in a Petri dish (50 mm diameter) using a cut tip (1.5 mm internal diameter). Twenty micro-litters of previously diluted sperm in immobilizing solution were pipetted on the egg mass and activated by adding $380 \mu \mathrm{L}$ of dechlorinated tap water. This procedure resulted in $312.5,625$, 1250, 2250, 4500 spermatozoa egg $^{-1} \mathrm{~mL}^{-1}$. Three control groups were prepared: egg batches inseminated with an excess of semen at the beginning (Co) and at the end (Cf) of fertilization trials, and an additional group "inseminated” with immobilizing solution (Cv).

Eggs were incubated at room temperature $\left(20-25^{\circ} \mathrm{C}\right)$. Dead eggs, evidenced by color whiteness were removed at 6h-intervals. When all the eggs from $\mathrm{Cv}$ were dead, live eggs from other treatments were supposed to be fertilized. Fertilization and hatching rates were calculated relative to the total amount of eggs.

\subsection{Thawing temperatures}


To evaluate the thawing temperatures, we adopted loach extender $(63.5 \mathrm{mM} \mathrm{NaCl}$, $114 \mathrm{mM} \mathrm{KCl,} 20 \mathrm{mM}$ Tris) and methanol $10 \%$ as a standard diluent based on our previous work (Yasui et al., 2008). Sperm samples were cryopreserved as mentioned previously. Three hours later, the straws were thawed at 20,25 and $30^{\circ} \mathrm{C}$ for $10 \mathrm{~s}$, and sperm parameters of total motility, progressive motility and its duration were measured.

\subsection{Activating solutions}

We compared the effects of dechlorinated tap water (DTW), distilled water (DW), 25 $\mathrm{mM} \mathrm{NaCl}$ and $50 \mathrm{mM} \mathrm{NaCl}$ as an activating solution in fresh (control) and cryopreserved sperm. Sperm from two males was pooled and cryopreserved using loach extender with $10 \%$ methanol. After three hours, the sperm samples were thawed and activated using the solutions mentioned above, and then measured the motility parameters.

\subsection{Internal cryoprotectants and extenders}

In this experiment we evaluated the effects of two extenders: loach extender and modified cyprinid extender (Lahnsteiner et al., 2000). The amount of $\mathrm{NaCl}$ and $\mathrm{KCl}$ on cyprinid extender was modified in order to increase osmolarity to $375 \mathrm{mOsm}$, obtaining the following final composition: $81.6 \mathrm{mM} \mathrm{NaCl}, 91.7 \mathrm{mM} \mathrm{KCl}, 2 \mathrm{mM} \mathrm{CaCl}, 1 \mathrm{mM} \mathrm{MgSO} 4,20$ $\mathrm{mM}$ Tris. Using both extenders, we evaluated the effects of five internal cryoprotectants (Dimethyl sulfoxide - DMSO, Dimethylacetamide - DMA, Methanol -MeOH, Ethylene Glycol - EG, and Glycerol - Gly) on post-thawed sperm parameters.

Each cryoprotectant was added to both extenders to provide a concentration of 0,5 , 10 and $15 \%$. Sperm from five males was cryopreserved, thawed at $25^{\circ} \mathrm{C}$ for $10 \mathrm{~s}$ and the post-thawed motility parameters were evaluated after three days of storage. Since dechlorinated tap water (DTW) did not change the sperm motility and it is a standard solution 
for artificial insemination, it was selected as a standard activating solution for the following experiments.

\subsection{External cryoprotectants}

Sperm from three males was pooled in immobilizing solution and diluted in loach extender with $10 \%$ methanol (selected based on previous experiments - see above), containing different external cryoprotectants at the following concentrations: BSA 1 and 2\%; sucrose 0.5 and $1 \%$; glucose 0.5 and $1 \%$; glycine 0.5 and $1 \%$. Samples were then frozen, thawed after three hours and assisted for the sperm parameters.

\subsection{Fertilizability and hatching rates}

Sperm from three males were pooled and frozen according to our best results on previous experiments (methanol $10 \%$ as an internal cryoprotectant; glycine $0.5 \%$ as external cryoprotectant; $25^{\circ} \mathrm{C}$ for 10 s for thawing; DTW as activating solution). Eggs from three females were fertilized using cryopreserved sperm at the minimum inseminating dose. Using the same dosage, we adopted three control groups: fresh sperm diluted in cyprinid extender, loach extender or immobilizing solution.

Fertilized eggs were maintained at room temperature $\left(22-25^{\circ} \mathrm{C}\right)$, and observed $60-90$ minutes after fertilization at 2-4 cell stage. The hatching rate was observed 30-50 hours postfertilization (HPF).

\subsection{Sperm cryopreservation of related species}

Based on the results obtained in previous experiments described above, the best procedure was used to cryopreserve the sperm from other loach species. For this experiment, one adult Misgurnus mizolepis ( 160 mm body lenght), three adults Lefua nikkonis ( 70 mm 
body lenght) and three adults Barbatula toni ( 120 mm body lenght) were utilized. $M$. mizolepis used in this study was the same utilized in our previous study (Fujimoto et al., 2008). B. toni were collected at Hekirichi river, Hokuto city, and L. nikkonis were collected at rice paddyfield in Hakodate-city area. After three hours of storage, the samples were thawed and the sperm parameters were evaluated.

\subsection{Statistics}

Data are shown as mean \pm SD. Quantitative data were analyzed using ANOVA succeeded by Student-Newman Keuls multiple range test. Inseminating dose was estimated by mean of regression analysis using the "linear response plateau" as model. Extenders were compared using a paired $t$-test. Statistical significance was set at 0.05 .

\section{Results}

\subsection{Inseminating dose for loach eggs}

The fertilization rate increased linearly until 684.42 spermatozoa $\mathrm{egg}^{-1} \mathrm{~mL}^{-1}$ (Fig. 1). Although the inseminating dose increased after this point, the fertilization rate was maintained constantly in a "plateau" of $62.84 \%$.

Similarly, the hatching rate increased linearly until 687.65 spermatozoa $\mathrm{egg}^{-1} \mathrm{~mL}^{-1}$, maintaining in a plateau of $61.16 \%$ (Fig. 2).

In the control groups Co and Cf, in which an excess of semen was employed, the average hatching rates obtained was $64 \pm 10 \%$ and $65 \pm 9 \%(n=6)$ at the beginning and at the end of fertilization trial, respectively. The results indicated that egg quality was not affected along the fertilization trials.

\subsection{Thawing temperatures}


The effects of thawing temperatures on sperm parameters are described on Table 1. Cryopreserved samples showed a decrease in total motility and duration when compared to fresh sperm. The thawing temperature did not affect the motility parameters of cryopreserved samples. Then, for the later stages, $25^{\circ} \mathrm{C}$ for $10 \mathrm{~s}$ was adopted as the thawing procedure

\subsection{Activating solutions}

Among fresh sperm, none of the sperm parameters were affected by the activating solutions (Table 4). Although the motility was not significantly affected by the activating solutions, the duration of motility was shorter when distilled water was employed, and longer duration was observed using 25 and $50 \mathrm{mM} \mathrm{NaCl}$ as sperm activators.

Among the cryopreserved samples, the utilization of different activating solutions did not affect total motility and progressive motility. However, the duration of progressive motility was increased when 25 or $50 \mathrm{mM} \mathrm{NaCl}$ were used for activation.

\subsection{Internal cryoprotectants and extenders}

During cryopreservation trials, the difference between sperm samples at the beginning of the experiment (fresh sperm 0 ) and at the end (fresh sperm ) $_{1}$ was not significant (Table 2). Thus, sperm samples maintained the quality during the experiment. In all the treatments, the parameters were affected when compared to control groups.

Extenders did not affect significantly the parameters of cryopreserved sperm, indicating that both extenders are equivalent. Methanol at 10 or $15 \%$ and DMA at $10 \%$ significantly improved the post-thawed sperm motility. No sperm motility was observed when glycerol and ethylene glycol were utilized at 15\%. 
Regarding progressive motility, all the cryopreserved samples showed a decrease when compared to fresh sperm. Considering together motility and progressive motility, better results were observed in treatments with methanol at 10 and $15 \%$ and DMA at $10 \%$.

\subsection{External cryoprotectants}

After cryopreservation, all the samples presented a decrease on sperm motility (Table 3). None of the external cryoprotectants improved sperm motility, progressive motility or its duration. However, better results were observed when glycine $0.5 \%$ or BSA $1 \%$ was utilized. BSA $2 \%$ decreased sperm quality. Then, glycine $0.5 \%$ was utilized for later experiments as also suggested by Lahnsteiner et al. (2000).

\subsection{Fertilization and hatching rates}

The results of fertilization trials are shown in Table 5. The dilution of semen using immobilizing solution or extenders did not affect the fertilization and the hatching rates, suggesting low toxicity of these solutions during fertilization. No differences on fertilization or hatching rates were observed between both extenders. Sperm parameters of cryopreserved sperm were significantly lower when compared to fresh samples.

\subsection{Sperm cryopreservation of loach species}

The initial sperm motility and progressive motility were higher than $80 \%$ in all sperm samples (Table 6). The duration of motility showed a clear specie-dependent trend, in which B. toni had the shortest duration $36.33 \pm 2.5 \mathrm{~s}$ followed by L. nikkonis (46.7 $\pm 2.0 \mathrm{~s}$ ) and $M$. mizolepis $(109.7 \pm 4.0 \mathrm{~s})$. All the sperm parameters between fresh and cryopreserved sperm did not differ in the loach species evaluated here (paired $t<0.05$ ). 


\section{Discussion}

The inseminating dose in the loach (684.42 spermatozoa $\mathrm{egg}^{-1} \cdot \mathrm{mL}^{-1}$ ) was lower than those observed in other fish species such as Cyprinus carpio (2000 spermatozoa egg-1, Magyary et al., 1996), Scophtalmus maximus (3000-9000 spermatozoa egg ${ }^{-1}$, Chereguini et al., 1999; Suquet et al., 1995), Coregonus lavaretus (300.000-500.000 spermatozoa egg-1, Lahnsteiner, 2000), Brycon insignis (314.000 spermatozoa egg $^{-1}$, Shimoda et al., 2007) and Petromyzon marinus (50.000 spermatozoa egg $^{-1}$, Ciereszko et al., 2000). The difference is probably related to gamete characteristics (oocyte diameter, sperm motility, its velocity and duration) as previously discussed by several authors (Gage et al., 2004; Lahnsteiner, 2000; Shimoda et al., 2007). The obtained dose in this study was utilized in all fertilization trials. This procedure provides an effective comparison between fresh and cryopreserved sperm (Billard and Zhang, 2001; Linhart et al., 2005, Lahnsteiner et al., 2003).

Thawing procedures at 20,25 and $30^{\circ} \mathrm{C}$ for 10 s were effective for $250 \mu \mathrm{L}$ cryogenic straws. We choose $25^{\circ} \mathrm{C}$ because this is a physiological (living and reproductive) temperature of the loach, and this temperature is easy to achieve using heating devices in our temperature conditions.

Among fresh samples, the utilization of DTW, DW, 25 or $50 \mathrm{mM} \mathrm{NaCl}$ did not affect sperm parameters. On the other hand, using 25 or $50 \mathrm{mM} \mathrm{NaCl}$, the duration of post-thaw sperm motility was increased. This suggests that cryopreserved samples are more sensitive to injuries related to medium osmolarity. Activating solutions containing higher osmolarities also optimized sperm motility in other fish species (Cacot et al., 2003; Jahnichen et al., 1999; Yao et al., 2000).

Methanol as an internal cryoprotectant significantly improved motility, progressive motility and its duration of cryopreserved sperm. Methanol was employed as successful internal cryoprotectant in other cypriniforms (Hypophthalmichtys molitrix -Alvarez et al 
2003; Tor khudree - Basavaraja and Hedge, 2004; Tinca tinca - Rodina et al., 2007; Cyprinus carpio - Horváth et al., 2003; Danio rerio - Harvey et al., 1984), although DMSO or DMA gave better results for most species (Hypophthalmichtys molitrix - Alvarez et al 2003; Cyprinus carpio - Babiak et al, 1997, Linhart et al., 2000; Ctenopharyngodon idella and Carassius auratus, - Babiak et al., 2000; Misgurnus fossilis - Kopeika et al., 2004; Lahnsteiner et al., 2000).

Differences were not observed in sperm parameters when cryopreserving with cyprinid or loach extenders, differing from Basavaraja and Hedge (2004) who have observed a clear interaction between cryoprotectants and extender. Considering that loach extender is simpler to prepare, it was used in most part of this study.

The utilization of external cryoprotectants did not show any significant improvement of cryopreserved samples.

During fertilization trials, it was demonstrated that the sperm quality and subsequent fertilizability of cryopreserved sperm has decreased significantly. Similar trends were also observed in Pangasius hypophtalmus (Kwantong and Bart, 2003) and in Cyprinus carpio (Warnecke and Pluta, 2003).

It was also demonstrated that the protocol of sperm cryopreservation of the loach is applicable for other loach species. Although other sperm cryopreservation protocols were established for other teleosts (Billard and Zhang, 2001), as far as we know, this is the first protocol for the loach species evaluated in this study. However, the cryopreservation procedures were not completely adjusted for these species. Optmization of parameters such as cooling rates, dilution ratio, cryoprotectants and thawing procedures may increase the cryopreservation success, since these parameters have a specie-specific trend (Billard and Zhang, 2001). In this trial, sperm parameters from cryopreserved or fresh sperm did not differ significantly, probably because a limited number of replications and fish might be employed. 
In conclusion, the sperm cryopreservation of the loach was optimized using the following procedure: loach or cyprinid extender; methanol $10 \%$ and glycine $0.5 \%$ as cryoprotectants; cooling in dry-ice at $-33.3 \pm 2.09{ }^{\circ} \mathrm{C} / \mathrm{min}$ from $0{ }^{\circ} \mathrm{C}$ to $-50{ }^{\circ} \mathrm{C} ; 25^{\circ} \mathrm{C}$ for $10 \mathrm{~s}$ as thawing procedure; 25 or $50 \mathrm{mM} \mathrm{NaCl}$ as activating solutions; 687.65 spermatozoa egg${ }^{1} \mathrm{~mL}^{-1}$ as the minimum inseminating dose. Using this protocol the fertilization rate decreased around 50\% when compared to fresh sperm. This protocol was also applicable for other loach species. 


\section{Acknowledgements}

This study was supported in part by Grants-in-Aid for the 21st Century COE program from Ministry of Education, Culture, Sports, Science and Technology of Japan (MEXT), for Scientific Research (B) (No. 18380108) from the Japanese Society for Promotion of Science (JSPS) to K.A. and that for Young Scientists (B) (No.18780138) from JSPS to T.F. 


\section{References}

Abe, T., Kobayashi, I., Kon, M. and Sakamoto, T., 2007. Spawning of the kissing loach (Leptobotia curta) is limited to periods following the formation of temporary waters. Zool. Sci., 24, 922-926.

Adámková-Stibranyiová, I., Adámek, Z., Šútovský I., 1999. A comparative study on the induced spawning in female loach (Misgurnus fossilis) by means of single and double pituitary injection technique. Czech J.Anim.Sci. 44, 403-407.

Alvarez, B., Fuentes R., Pimentel R., Abad Z., Cabrera E., Pimentel E., Arenal A., 2003. High fry production rates using post-thaw silver carp (Hypophthalmichtys molitrix) spermatozoa under farming conditions. Aquaculture 220, 195-201.

Aoyama, S., Doi, T., 2005. Spawning site of the fluvial eight-barbel loach, Lefua sp., in the natural environment. Ichthyol. Res. 53, 107-112.

Arai, K., 2001. Genetic improvement of aquaculture finfish species by chromosome manipulation techniques in Japan. Aquaculture 197, 205-228.

Arai K., 2003. Genetics of the loach Misgurnus anguillicaudatus: recent progress and perspectives. Folia Biol. 51, 107-117.

Arai, K., Ikeno, M., Suzuki, R., 1995. Production of androgenetic diploid loach Misgurnus anguillicaudatus using spermatozoa of natural tetraploids. Aquaculture 137, 131-138.

Araki, K., Shinma, H., Nagoya, H., Nakayama, I. \& Onozato, H., 1995. Androgenetic diploids of rainbow trout (Oncorhynchus mykiss) produced by fused sperm. Can. J. Fish. Aq. Sci. 52, 892-896. 
Babiak, I., Glogowski, J., Brzuska, E., Szumiec, J., Adamek, J., 1997. Cryopreservation of sperm of common carp, Cyprinus carpio L. Aquac. Res. 28, 567-571.

Babiak, I., Brzuska, E., Perkowski, J., 2000. Fractional factorial design of screening experiments on cryopreservation of fish sperm. Aquac. Res. 31, 273-282.

Basavaraja, N., Hegde, S.N., 2004. Cryopreservation of the endangered mahseer (Tor khudree) spermatozoa: I. Effect of extender composition, cryoprotectants, dilution ratio, and storage period on post-thaw viability. Cryobiology 49,149-156.

Bercsányi, M., Magyáry, I., Urbányi, B., Orbán, L., Horváth, L., 1998. Hatching out goldfish from common carp eggs: interspecific androgenesis between two cyprinid species. Genome 41, 573-579.

Billard, R., Zhang, T., 2001 Techniques of genetic resource banking in fish. In: Watson, P.F., Holt. W.V. (Ed.) Cryobanking the genetic resource: wildlife conservation for the future? Taylor and Francis, London, pp.156-170.

Bohlen, J., 1999. Reproduction of spined loach, Cobitis taenia (Cypriniformes, Cobitidae) under laboratory conditions. J. Appl. Ichthyol. 15, 49-53.

Cacot, P., Eeckhoutte, P., Muon, D.T., Trieu, N.V., Legendre, M., Mariojouls C., Lazard, J., 2003. Induced spermiation and milt management in Pangasius bocourti (Sauvage, 1880). Aquaculture 215, 67-77.

Chereguini, O., de La Banda, I., Rasines, I., Fernandez, A., 1999. Artificial fertilization in turbot, Scophthalmus maximus (L.): different methods and determination of the optimal sperm-egg ratio. Aquac. Res. 30, 319-324. 
Ciereszko, A., Glogowski, J., Dabrowski, K., 2000 Fertilization in landlock sea lamprey: storage of gametes, optimal sperm:egg ratio, and methods of assessing fertilization success. J. Fish Biol. 56, 495-505.

Fujimoto, T., Sakao, S., Yamaha, E., Arai, K., 2007. Evaluation of different doses of UV irradiation to loach eggs for genetic inactivation of the maternal genome. J. Exp. Zool. 307A, 449-462.

Fujimoto, T. , Yasui, G. S., Yoshikawa, H., Yamaha, E., Arai, K., 2008. Genetic and reproductive traits of spermatozoa from diploid and triploid hybrid males between Misgurnus anguillicaudatus female and M. mizolepis male. J. Appl. Ichthyol. 24, 430-437.

Gage, M.J.G., Macfarlane, C.P., Yeates, S., Ward, R.G., Searle, J.B., Parker, G.A., 2004. Spermatozoal traits and sperm competition in Atlantic salmon: relative sperm velocity is the primary determinant of fertilization success. Curr. Biol., 14, 44-47.

Harvey, B., Kelley, R.N., Ashwood-Smith, M.J., 1984. Cryopreservation of zebra fish spermatozoa using methanol. Can. J. Zool. 60, 1867-1870.

Horváth, A., Miskolczi, E., Urbányi, B., 2003. Cryopreservation of common carp sperm. Aquat. Living Resour. 16, 457-460.

Iwamatsu, T., Ishima, S., Nakashima, S., 1993. Movement of spermatozoa and changes in micropyles durind fertilization in medaka eggs. J. Exp. Zool. 266, 57-64.

Jahnichen, H., Warnecke, D., Trolsch, E., Kohlmannn, K., Bergler, H., Pluta, H.J., 1999. Motility and fertilizing capability of cryopreserved, Acipenser ruthenus L. sperm. J. Appl. Ichthyol. 15, 204-206. 
Kopeika, J., Kopeika, E., Zhang, T., Rawson, D.M., Holt, W.V. 2003. Detrimental effects of cryopreservation of loach (Misgurnus fossilis) sperm on subsequent embryo development are reversed by incubating fertilised eggs in caffeine. Cryobiology 46, 43-52.

Kopeika, J., Kopeika, E., Zhang, T., Rawson, D.M., Holt, W.V. 2004. Effect of DNA repair inhibitor 3-Aminobenzamide on genetic stability of loach (Misgurnus fossilis) embryos derived from cryopreserved sperm. Theriogenology 61, 1661-1673.

Kurokura, H., Hirano, R., Tomita, M., Iwahashi, M., 1984. Cryopreservation of carp sperm. Aquaculture 37, 267-273.

Kwantong, S., Bart, A.N., 2003. Effect of cryoprotectants, extenders and freezing rates on the fertilization rate of frozen striped catfish, Pangasius hypophtalmus. Aquac. Res., 34, 887893.

Lahnsteiner, F., 2000. Semen cryopreservation in the salmonidae and in the northern pike. Aquac. Res. 31, 245-258.

Lahnsteiner, F., Berger, B., Horvath, A., Urbanyi, B., Weismann T., 2000. Cryopreservation of spermatozoa in cyprinid fishes. Theriogenology 54, 1477-98.

Lahnsteiner, F., Berger, B., Weismann T., 2003. Effects of media, fertilization technique, extender, straw volume, and sperm to egg ratio on hatchability of cyprinid embryos, using cryopreserved semen. Theriogenology 60, 829-41.

Linhart, O., Rodina, M., Cosson, J., 2000. Cryopreservation of sperm in common carp Cyprinus carpio: sperm motility and hatching success of embryos. Cryobiology 41, 241-50. 
Linhart, O., Rodina, M., Flajshans, M., Gela, D., Kocour, M. 2005. Cryopreservation of European catfish Silurus glanis sperm: sperm motility, viability, and hatching success of embryos. Cryobiology 51, 250-261.

Masaoka, T., Arai, K., Suzuki, R., 1995. Production of androgenetic diploid loach, Misgurnus anguillicaudatus from UV irradiated eggs by supression of the first cleavage. Fish. Sci. 61, 716-717.

Nakagawa, M., Kobayashi, T., Ueno, K., 2002. Production of germline chimera in loach (Misgurnus anguillicaudatus) and proposal of new method for preservation of endangered fish species. J. Exp. Zool. 293, 624-631.

Nam, Y.K., Noh, J.K., Cho, Y.S., Cho, H.J., Kyu-Nam, C., Kim, C.G., Kim, D.S., 2001. Dramatically accelerated growth and extraordinary gigantism of transgenic mud loach Misgurnus mizolepis. Transgenic Res. 10, 353-362.

Nelson J.S., 2006. Fishes of the world, third edition. John Wiley and Sons, New York.

Rodina, M., Gela, D., Kocour, M., Hadi, S.M.H., Hulak, M., Linhart, O. 2007. Cryopreservation of tench, Tinca tinca, sperm: sperm motility and hatching success of embryos. Theriogenology, 67, 931-940.

Shimoda E., Andrade D.R., Vidal Júnior M.V., Godinho H.P. and Yasui G.S. 2007. Determination of the optimum ratio of spermatozoa per oocyte of the piabanha Brycon insignis. Arq. Bras. Med. Vet. Zootec., 59, 877-882 (In Portuguese with English abstract).

Slechtova, V., Bohlen, J., Tan, H.H., 2007. Families of Cobitoidea (Teleostei; Cypriniformes) as revealed from nuclear genetic data and the position of the mysterious genera Barbucca, Psilorhynchus, Serpenticobitis and Vaillantella. Mol. Phylogenet. Evol., 44, 1358-1365. 
Slechtova, V., Bohlen, J., Perdices A. 2008. Molecular phylogeny of the freshwater fish family Cobitidae (Cypriniformes: Teleostei): delimitation of genera, mitochondrial introgression and evolution of sexual dimorphism. Mol. Phylogenet. Evol., 47, 812-831.

Suquet, M., Billard, R., Cosson, J., Normant, Y., Fauvel C., 1995. Artificial insemination in turbot (Scophthalmus maximus): determination of the optimal sperm to egg ratio and time of gamete contact. Aquaculture, 133, 83-90.

Tanaka, D., Takahashi, A., Ueno, K., 2009. Morphometric characteristics and reproductive capacity of nuclear transplants derived from embryonic cells of loach, Misgurnus anguillicaudatus. J. Exp. Zool. 311A, 11-19.

Trippel, E.A., Neilson, J.D., 1992. Fertility and sperm quality of virgin and repeat spawning Atantic cod (Gadus morhua) and associated hatching sucess. Can. J. Fish. Aquat. Sci. 49, 2118-2127.

Warnecke, D., Pluta, H.J., 2003. Motility and fertilizing capacity of frozen/thawed common carp (Cyprinus carpio L.) sperm using dimethyl-acetamide as the main cryoprotectant. Aquaculture 215, 167-185.

Watanabe, K., Takeshima, H., Iwata, A., Abe, T., Uehara, K., Kakioka, K., Kihira D., Nishida, M., 2008. Isolation and characterization of 39 microsatellite loci in the endangered Japanese loach Leptobotia curta. Mol. Ecol. Res., 8, 145-148.

Yao, Z., Crim, L.W., Richardson, G.F., Emerson, C.J., 2000. Motility, fertility and ultrastructural changes of ocean pout (Macrozoarces americanus L.) sperm after cryopreservation. Aquaculture 181, 361-375. 
Yasui, G.S., Arias-Rodriguez, L., Fujimoto, T., Arai, K. (2008) Simple and inexpensive method for cryopreservation of fish sperm combining straw and powdered dry ice. Cryoletters 29, 383-390. 


\section{Figure Legends}

Fig. 1. Fertilization rate of loach eggs at increasing inseminating dosages. Dosages higher than 684.42 spermatozoa egg $^{-1} \mathrm{~mL}^{-1}$ had fertilization rates of $62.84 \%$

Fig. 2. Hatching rate of the eggs inseminated at increasing dosages. Dosages higher than 687.65 spermatozoa egg $^{-1} \mathrm{~mL}^{-1}$ had hatching rate of $61.16 \%$. 


\section{Tables}

Table 1. Sperm parameters of fresh and post-thawed sperm thawed at different temperatures. Motility refers to all motile cells. Progressive motility is expressed as percentage of motile cells and duration of motility regards to the time elapsed from activation until $5 \%$ of progressive motility.

\begin{tabular}{cccc}
\hline Thawing temperature & Motility (\%) & Progressive motility (\%) & Duration (s) \\
\hline Fresh sperm & $>90 \%^{\mathrm{a}}$ & $>90 \%^{\mathrm{a}}$ & $247 \pm 16^{\mathrm{a}}$ \\
$20^{\circ} \mathrm{C}$ for 10s. & $68 \pm 08^{\mathrm{b}}$ & $82 \pm 10^{\mathrm{a}}$ & $142 \pm 07^{\mathrm{b}}$ \\
$25^{\circ} \mathrm{C}$ for 10s. & $72 \pm 03^{\mathrm{b}}$ & $83 \pm 06^{\mathrm{a}}$ & $146 \pm 12^{\mathrm{b}}$ \\
$30^{\circ} \mathrm{C}$ for 10s. & $70 \pm 10^{\mathrm{b}}$ & $73 \pm 15^{\mathrm{a}}$ & $138 \pm 19^{\mathrm{b}}$ \\
\hline
\end{tabular}

Values with the same superscript letter are not significantly different $(P<0.05)$. 
Table 2. Effects of internal cryoprotectants and its concentration on sperm parameters, using loach extender and cyprinid extender ( $n=3)$. Motility refers to all motile cells. Progressive motility is expressed as percentage of motile cells and duration of motility regards to the time elapsed from activation until 5\% of progressive motility.

\begin{tabular}{|c|c|c|c|}
\hline Treatment & Motility (\%) & Progressive motility (\%) & Duration (s) \\
\hline Fresh sperm $_{0}$ & $>90^{\mathrm{a}}$ & $>90^{\mathrm{a}}$ & $217 \pm 64^{\mathrm{a}}$ \\
\hline Fresh sperm $_{1}$ & $>90^{\mathrm{a}}$ & $>90^{\mathrm{a}}$ & $230 \pm 11^{\mathrm{a}}$ \\
\hline DMSO 5\% & $17.5 \pm 7.6^{\mathrm{d}}$ & $50.0 \pm 15.5^{\mathrm{cd}}$ & $67.2 \pm 13.3^{\mathrm{e}}$ \\
\hline DMSO 10\% & $45.0 \pm 18.7^{\mathrm{c}}$ & $51.7 \pm 14.7^{\mathrm{cd}}$ & $70.8 \pm 14.4^{\mathrm{e}}$ \\
\hline DMSO $15 \%$ & $15.8 \pm 8.0^{\mathrm{d}}$ & $46.7 \pm 13.7^{\mathrm{d}}$ & $62.7 \pm 15.2^{\mathrm{e}}$ \\
\hline DMA 5\% & $12.5 \pm 5.2^{\mathrm{de}}$ & $60.0 \pm 15.5^{\mathrm{bcd}}$ & $56.0 \pm 8.2^{\mathrm{e}}$ \\
\hline DMA $10 \%$ & $64.1 \pm 10.2^{\mathrm{b}}$ & $65.0 \pm 8.3^{\mathrm{bcd}}$ & $63.2 \pm 9.3^{\mathrm{e}}$ \\
\hline DMA $15 \%$ & $20.8 \pm 8.0^{\mathrm{d}}$ & $46.7 \pm 16.3^{d}$ & $52.5 \pm 13.1^{\mathrm{e}}$ \\
\hline Glycerol 5\% & $9.2 \pm 5.8^{\mathrm{de}}$ & $70.8 \pm 7.3^{\mathrm{bc}}$ & $68.3 \pm 12.1^{\mathrm{e}}$ \\
\hline Glycerol 10\% & $16.7 \pm 9.6^{\mathrm{d}}$ & $62.5 \pm 18.9^{\mathrm{bcd}}$ & $102.2 \pm 34.4^{\mathrm{cd}}$ \\
\hline Glycerol 15\% & $0.0 \pm 0.0^{\mathrm{e}}$ & $0.0 \pm 0.0^{\mathrm{e}}$ & $0.0 \pm 0.0^{f}$ \\
\hline MeOH 5\% & $39.1 \pm 13.6^{\mathrm{c}}$ & $61.7 \pm 12.1^{\mathrm{bcd}}$ & $82.3 \pm 11.6^{\mathrm{de}}$ \\
\hline MeOH 10\% & $70.0 \pm 3.2^{\mathrm{b}}$ & $74.2 \pm 4.9^{b}$ & $117.2 \pm 14.2^{\mathrm{bc}}$ \\
\hline MeOH 15\% & $71.7 \pm 4.1^{\mathrm{b}}$ & $71.7 \pm 7.5^{\mathrm{bc}}$ & $134.0 \pm 10.7^{\mathrm{b}}$ \\
\hline Ethylene Glycol 5\% & $15.0 \pm 7.7^{\mathrm{d}}$ & $55.0 \pm 10.5^{\mathrm{bcd}}$ & $67.5 \pm 11.1^{\mathrm{e}}$ \\
\hline Ethylene Glycol 10\% & $9.2 \pm 3.8^{\text {de }}$ & $48.3 \pm 16.1^{\mathrm{d}}$ & $54.5 \pm 18.0^{\mathrm{e}}$ \\
\hline Ethylene Glycol 15\% & $0.0 \pm 0.0^{\mathrm{e}}$ & $0.0 \pm 0.0^{\mathrm{e}}$ & $0.0 \pm 0.0^{f}$ \\
\hline
\end{tabular}

Values with the same superscript letter are not significantly different $(P<0.05)$. 
Table 3. Effects of external cryoprotectants and its concentration on sperm parameters. Cryopreserved sperm without external cryoprotectants was considered the control group. Motility refers to all motile cells. Progressive motility is expressed as percentage of motile cells and duration of motility regards to the time elapsed from activation until $5 \%$ of progressive motility.

\begin{tabular}{lccc}
\hline \multicolumn{1}{c}{ Treatment } & Motility (\%) & Progressive motility (\%) & Duration (s) \\
\hline Fresh sperm & $>90^{\mathrm{a}}$ & $>90^{\mathrm{a}}$ & $205 \pm 03^{\mathrm{a}}$ \\
Control (10\% methanol) & $73 \pm 06^{\mathrm{bc}}$ & $72 \pm 03^{\mathrm{b}}$ & $146 \pm 09^{\mathrm{b}}$ \\
Sucrose 0.5\% & $73 \pm 06^{\mathrm{bc}}$ & $73 \pm 06^{\mathrm{b}}$ & $140 \pm 05^{\mathrm{b}}$ \\
Sucrose 1\% & $75 \pm 07^{\mathrm{bc}}$ & $80 \pm 14^{\mathrm{ab}}$ & $132 \pm 10^{\mathrm{b}}$ \\
BSA 1\% & $80 \pm 05^{\mathrm{b}}$ & $87 \pm 06^{\mathrm{ab}}$ & $141 \pm 02^{\mathrm{b}}$ \\
BSA 2\% & $53 \pm 16^{\mathrm{c}}$ & $77 \pm 06^{\mathrm{b}}$ & $137 \pm 09^{\mathrm{b}}$ \\
Glycine 0.5\% & $78 \pm 03^{\mathrm{b}}$ & $88 \pm 03^{\mathrm{ab}}$ & $149 \pm 08^{\mathrm{b}}$ \\
Glycine 1\% & $73 \pm 08^{\mathrm{bc}}$ & $78 \pm 08^{\mathrm{ab}}$ & $143 \pm 27^{\mathrm{b}}$ \\
Glucose 0.5\% & $75 \pm 05^{\mathrm{bc}}$ & $80 \pm 10^{\mathrm{ab}}$ & $144 \pm 26^{\mathrm{b}}$ \\
Glucose 1\% & $70 \pm 10^{\mathrm{bc}}$ & $77 \pm 06^{\mathrm{b}}$ & $120 \pm 12^{\mathrm{b}}$ \\
\hline
\end{tabular}

Values with the same superscript letter are not significantly different $(P<0.05)$. 
Table 4. Sperm parameters of fresh and cryopreserved sperm activated with dechlorinated tap water (DTW), distilled water (DW) and 25 and $50 \mathrm{mM} \mathrm{NaCl}(n=3)$. Motility refers to all motile cells. Progressive motility is expressed as percentage of motile cells and duration of motility regards to the time elapsed from activation until 5\% of progressive motility.

Activating solution $\quad$ Motility (\%) Progressive motility (\%) Duration (s)

\section{Fresh sperm}

$\begin{array}{llll}\text { DTW } & >90 \%^{\mathrm{a}} & 92 \pm 03^{\mathrm{a}} & 247 \pm 16^{\mathrm{ab}} \\ \text { DW } & >90 \%^{\mathrm{a}} & 87 \pm 06^{\mathrm{a}} & 183 \pm 69^{\mathrm{ab}} \\ 25 \mathrm{mM} \mathrm{NaCl} & >90 \%^{\mathrm{a}} & 87 \pm 06^{\mathrm{a}} & 288 \pm 60^{\mathrm{a}} \\ 50 \mathrm{mM} \mathrm{NaCl} & >90 \%^{\mathrm{a}} & 86 \pm 06^{\mathrm{a}} & 286 \pm 53^{\mathrm{a}}\end{array}$

\section{Cryopreserved sperm}

\begin{tabular}{llll} 
DTW & $72 \pm 03^{\mathrm{b}}$ & $83 \pm 06^{\mathrm{a}}$ & $146 \pm 12^{\mathrm{b}}$ \\
DW & $73 \pm 06^{\mathrm{b}}$ & $80 \pm 05^{\mathrm{a}}$ & $142 \pm 20^{\mathrm{b}}$ \\
$25 \mathrm{mM} \mathrm{NaCl}$ & $77 \pm 06^{\mathrm{b}}$ & $78 \pm 03^{\mathrm{a}}$ & $219 \pm 46^{\mathrm{ab}}$ \\
$50 \mathrm{mM} \mathrm{NaCl}$ & $75 \pm 05^{\mathrm{b}}$ & $83 \pm 03^{\mathrm{a}}$ & $247 \pm 21^{\mathrm{ab}}$ \\
\hline
\end{tabular}

Identical superscript letters after the mean values represent non-significant differences within columns at the $5 \%$ level by the Student-Newman-Keuls test. 
Table 5. Fertilization and hatching rates of the eggs fertilized with post-thawed or fresh sperm at optimum inseminating dose $(n=3)$.

\begin{tabular}{lcc}
\hline \multicolumn{1}{c}{ Treatment } & Fertilization rate (\%) & Hatching rates (\%) \\
\hline Fresh sperm & $68 \pm 08^{\mathrm{a}}$ & $67 \pm 08^{\mathrm{a}}$ \\
$\begin{array}{l}\text { Fresh sperm diluted in cyprinid } \\
\text { extender }\end{array}$ & $60 \pm 12^{\mathrm{a}}$ & $58 \pm 14^{\mathrm{a}}$ \\
Fresh sperm diluted in loach extender & $74 \pm 08^{\mathrm{a}}$ & $74 \pm 09^{\mathrm{a}}$ \\
$\begin{array}{l}\text { Cryopreserved sperm in cyprinid } \\
\text { extender }\end{array}$ & $28 \pm 06^{\mathrm{b}}$ & $28 \pm 06^{\mathrm{b}}$ \\
Cryopreserved sperm in loach extender & $32 \pm 07^{\mathrm{b}}$ & $29 \pm 04^{\mathrm{b}}$ \\
\hline
\end{tabular}

Identical superscript letters after the mean values represent non-significant differences within columns at the $5 \%$ level by the Student-Newman-Keuls test. 
Table 6. Sperm parameters of loach species of fresh and cryopreserved samples. Sperm was cryopreserved using $M$. anguillicaudatus protocol ( $n=3)$. Motility refers to all motile cells. Progressive motility is expressed as percentage of motile cells and duration of motility regards to the time elapsed from activation until 5\% of progressive motility.

\begin{tabular}{lccc}
\hline \multicolumn{1}{c}{ Sample } & Motility (\%) & Progressive motility (\%) & Duration (s) \\
\hline Fresh sperm & & & \\
$\quad$ Barbatula toni & $83.3 \pm 2.8$ & $86.6 \pm 5.8$ & $36.3 \pm 2.5$ \\
Lefua nikkonis & $90.0 \pm 0.0$ & $90.0 \pm 0.0$ & $46.7 \pm 2.0$ \\
Misgurnus mizolepis & $86.6 \pm 5.8$ & $86.6 \pm 5.8$ & $109.7 \pm 4.0$ \\
Cryopreserved sperm & & & \\
Barbatula toni & $60.0 \pm 5.0$ & $73.3 \pm 2.9$ & $24.33 \pm 2.5$ \\
Lefua nikkonis & $58.33 \pm 7.6$ & $76.7 \pm 5.8$ & $33.3 \pm 3.2$ \\
Misgurnus mizolepis & $63.3 \pm 5.7$ & $81.7 \pm 2.9$ & $86.33 \pm 8.5$ \\
\hline
\end{tabular}




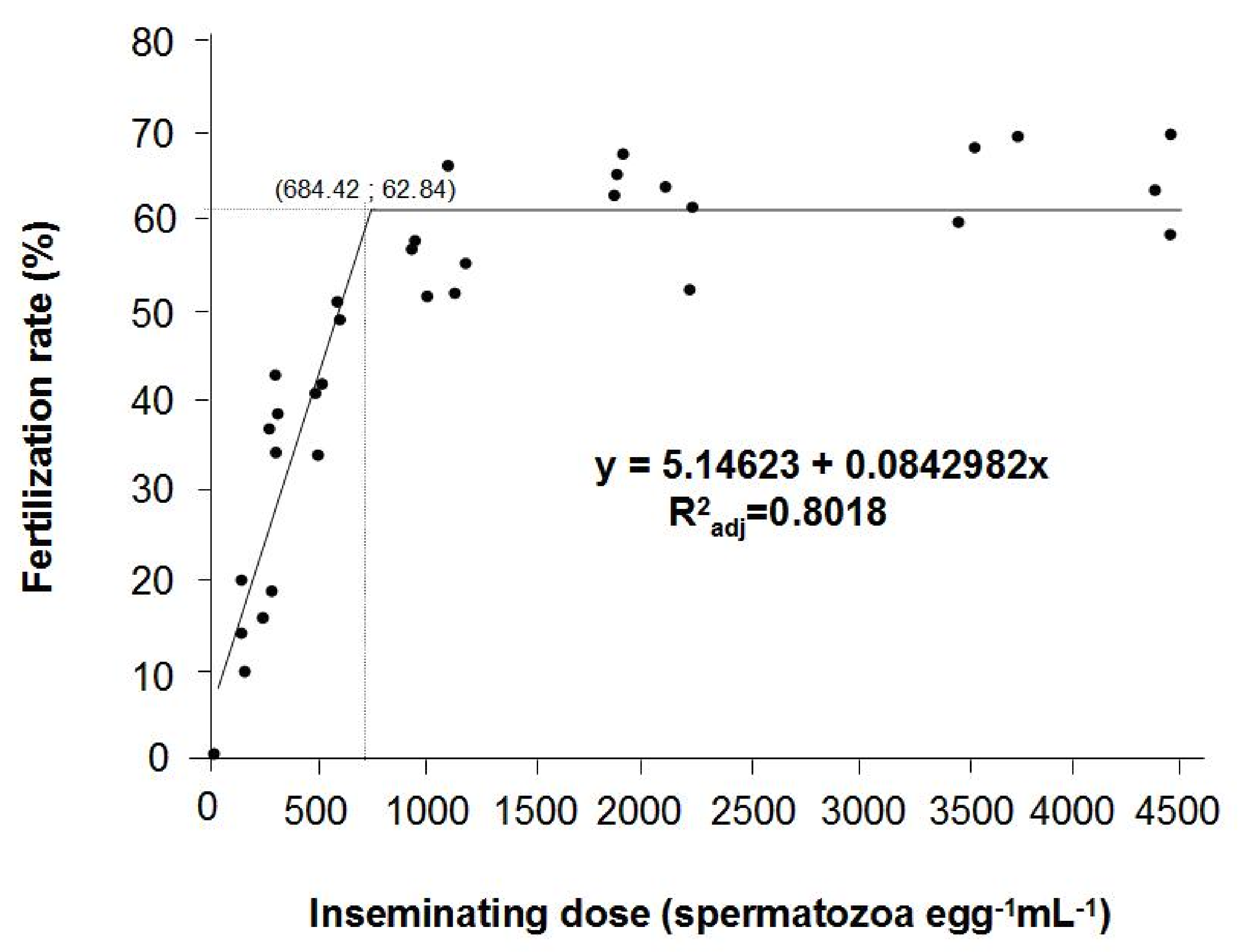




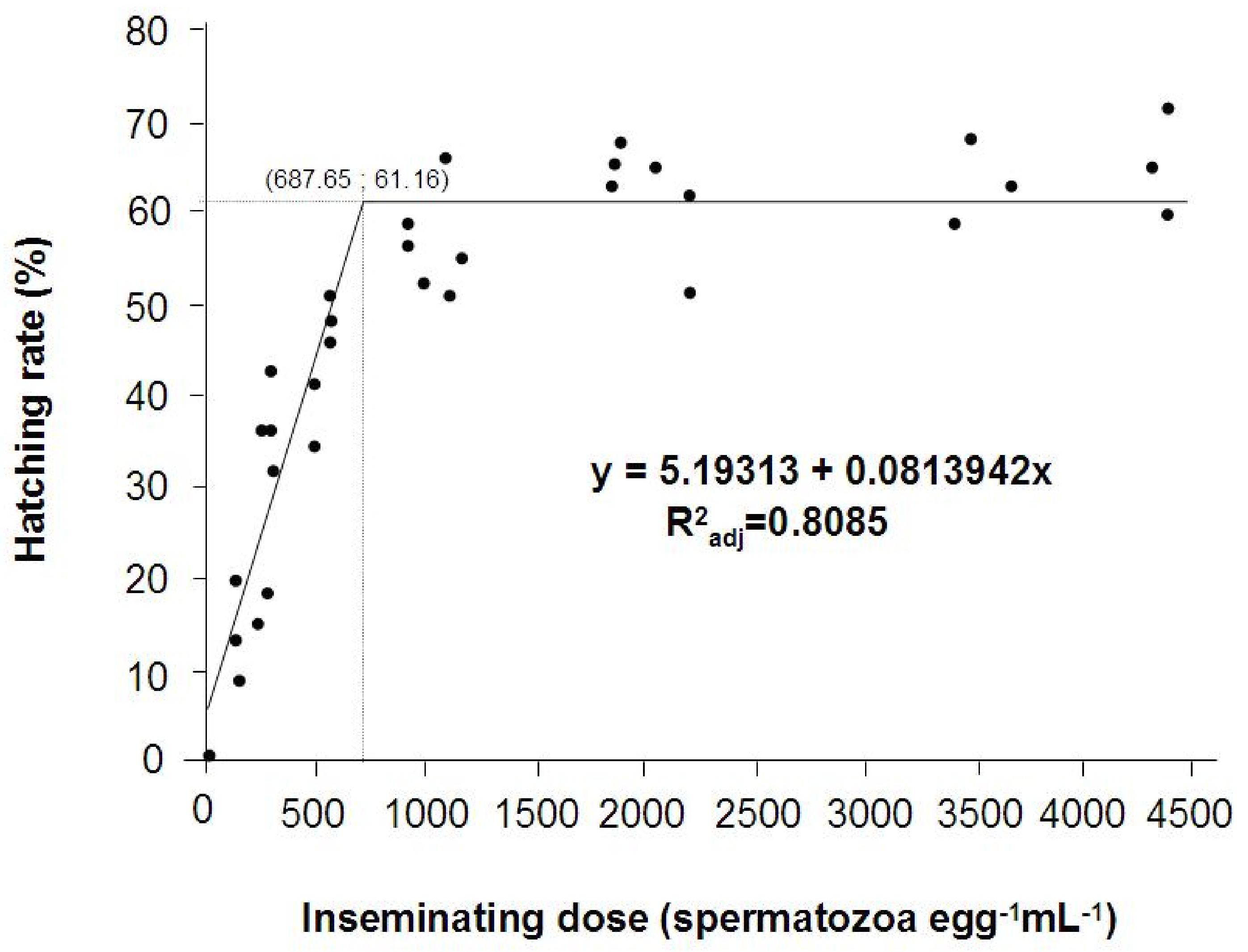

